Article

\title{
Preparation of KI/Hydroxyapatite Catalyst from Phosphate Rocks and Its Application for Improvement of Biodiesel Production
}

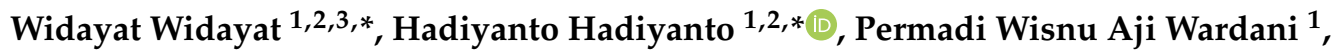 \\ Ummi Az Zuhra ${ }^{1}$ and Jedy Prameswari ${ }^{1,2, *}$ \\ 1 Chemical Engineering Department, Faculty of Engineering, Diponegoro University, \\ Semarang 50271, Indonesia; wisnupandhef@students.undip.ac.id (P.W.A.W.); \\ ummiazzuhra@students.undip.ac.id (U.A.Z.) \\ 2 Center of Biomass and Renewable Energy, Diponegoro University, Semarang 50271, Indonesia \\ 3 Advanced Materials Research Laboratory, Diponegoro University, Semarang 50271, Indonesia \\ * Correspondence: widayat@lecturer.undip.ac.id (W.W.); hadiyanto@live.undip.ac.id (H.H.); \\ jedyprameswari@students.undip.ac.id (J.P.)
}

Academic Editor: Giorgio Vilardi

Received: 3 April 2020; Accepted: 18 May 2020; Published: 31 May 2020

\begin{abstract}
The main aim of this work was to investigate the suitability of a $\mathrm{KI} / \mathrm{KIO}_{3}$ impregnated hydroxyapatite (HAP) catalyst derived from natural phosphate rocks for biodiesel production. This study evaluated the effect of impregnation concentrations $(1-6 \% w / w)$ on the catalyst performance in biodiesel production. The biodiesel was produced from waste cooking oil (WCO) under simultaneous esterification-transesterification reactions at $60^{\circ} \mathrm{C}$ for $6 \mathrm{~h}$. The results showed that the biodiesel yield increased by increasing impregnation concentration and the maximum yield $(91.787 \%)$ was achieved at an impregnation concentration of $5 \% w / w$. The KI/HAP catalyst showed better performance (91.78\% biodiesel yield, 59.1\% FAME yield and surface area of $13.513 \mathrm{~m}^{2} / \mathrm{g}$ ) as compared to the $\mathrm{KIO}_{3} / \mathrm{HAP}$ catalyst $\left(90.07 \%\right.$ biodiesel yield, $55.0 \%$ FAME yield and surface area of $10.651 \mathrm{~m}^{2} / \mathrm{g}$ ).
\end{abstract}

Keywords: biodiesel; $\mathrm{HAP}$; impregnation $\mathrm{KI} / \mathrm{KIO}_{3}$; simultaneous reaction; waste cooking oil

\section{Introduction}

Increasing demand for fossil fuel has led to extensive energy exploration. Biodiesel or fatty acids methyl esters (FAME) is a vegetable-derived fuel and considered as an alternative for conventional diesel fuel. Several advantages of biodiesel include the high flash point, biodegradability and lower gas emission [1]. An oil source which contains high free fatty acids (FFAs) such as waste cooking oil (WCO) is now being used for biodiesel synthesis, as they are less expensive than refined oil, and it offers significant advantages i.e., reduction in environmental impacts. Biodiesel from waste cooking oil has been successfully derived with simultaneous esterification and transesterification process using a homogenous catalyst [2]. Conventionally, the biodiesel synthesis uses homogenous catalyst either acid or base catalysts. The homogenous acid catalysts for esterification are $\mathrm{H}_{2} \mathrm{SO}_{4}$, $\mathrm{HCl}, \mathrm{H}_{3} \mathrm{PO}_{4}, \mathrm{HNO}_{3}$ and the base catalysts are $\mathrm{KOH}$ and $\mathrm{NaOH}$. The drawbacks of these homogenous catalysts are long reaction times (3-4 h) and they require complex separation of final products and neutralization process $[3,4]$. Although liquid acid catalysts likely give higher biodiesel yield, the corrosiveness and slower reaction are the main disadvantages as compared to the base catalyst $[4,5]$. As a consequence of these drawbacks, many studies are being developed to investigate heterogeneous catalysts because of their non-corrosive properties, large surface area and easiness of separation from biodiesel $[4,6]$. The common heterogeneous catalysts are immobilized lipase, calcium and magnesium 
oxides, as well as ion exchange resins [4,5,7]. However, the heterogeneous catalysts are mostly used only on the transesterification reaction and therefore, it is required to investigate the application of these catalyst on simultaneous reactions of esterification and transesterification for efficient and economical considerations [8].

Hydroxyapatite $\mathrm{Ca}_{10}(\mathrm{PO} 4)_{6}(\mathrm{OH})_{2}(\mathrm{HAP})$ is a low-cost mineral catalyst in biodiesel synthesis which could be derived from eggshells, prawn shells, animal bones, mollusk shells and phosphate rocks. Phosphate is an element found in frozen rock sediments containing apatite mineral, which is abundant in nature. It is approximated that the world has a natural phosphate rocks deposit of 87,810 million tons, with the largest deposits in North Africa (41.453\%), followed by West Africa $(20.840 \%)$ and North America (14.805\%). Indonesia has a deposit of 18.961 million tons of phosphate rocks, accounting for $0.774 \%$ of the total deposit in the world, with a $\mathrm{P}_{2} \mathrm{O}_{5}$ content ranging from $6.25 \%$ to $49.3 \%$ [9]. In Sukolilo, Pati, Central Java, Indonesia, there is a deposit of 85,000 tons of phosphate rocks with a $25-35 \% \mathrm{P}_{2} \mathrm{O}_{5}$ content. The utilization of phosphate rocks in Indonesia is still limited to phosphoric acid and phosphate fertilizer production [9], therefore ensuring the sustainability of phosphate rocks as raw material. Recent studies have found HAP to be a potential catalyst for biodiesel production due to its advantage in ion-exchange, adsorption capacity, non-toxic nature and thermal stability [10]. Moreover, the strong acidic active site of HAP will greatly benefit the esterification process in the simultaneous reaction. Essemlali et al. [11] conducted a piece of research on $\mathrm{Na} / \mathrm{HAP}$ catalyst synthesis by evaluating the effect of mass ratio between $\mathrm{NaNO}_{3}$ and calcination temperature and obtained biodiesel yield above $90 \%$. Chen et al. [12] also conducted a piece of research on synthesizing a K/HAP catalyst from animal bones and obtained a biodiesel yield above $90 \%$.

In this study, $\mathrm{KI}$ and $\mathrm{KIO}_{3}$ were used with $\mathrm{HAP}$ (as support) for biodiesel catalysis, due to the fact that potassium was relatively more effective [12]. Moreover, $\mathrm{KI}_{\text {and }} \mathrm{KIO}_{3}$ have shown high catalytic activity in transesterification reaction due to its strong basic active sites, as evidenced by Islam et al. [13] who obtained a $98 \%$ biodiesel yield using a $\mathrm{KI} / \gamma-\mathrm{Al}_{2} \mathrm{O}_{3}$ catalyst. Malani et al. [14] used a $\mathrm{KI} / \mathrm{ZnO}$ catalyst resulting in $92.35 \%$ biodiesel yield, Tantirungrotechai et al. [15] used a KI/Mg-Al catalyst resulting in an above $90 \%$ biodiesel yield and Jairam et al. [16] used a KI/oyster shell catalyst resulting in $85 \%$ biodiesel yield. Therefore, $\mathrm{KI}$ and $\mathrm{KIO}_{3}$ supported by HAP have shown their potencies as catalyst for simultaneous reaction heterogeneous catalyst.

This research aimed to (i) evaluate the effect of varying $\mathrm{KI}$ and $\mathrm{KIO}_{3}$ impregnation concentration to the HAP catalyst, (ii) analyze the characteristics of the catalysts with XRD, SEM, BET and FTIR analyses, and (iii) apply the catalyst to biodiesel production through a one step simultaneous esterification-transesterification process.

\section{Materials and Methods}

\subsection{Materials}

Natural phosphate rocks used in this research were taken from Sukolilo, Pati Regency, Central Java, Indonesia. Waste cooking oil (WCO) was obtained from several restaurants in Tembalang, Semarang, Indonesia. Other materials used were distilled water, $\mathrm{HNO}_{3}(65 \%$, Merck, Darmstadt, Germany), $\mathrm{NH}_{4} \mathrm{OH}$ (25\%, Merck, Darmstadt, Germany), $\mathrm{KIO}_{3}$ (99.8\%, Merck, Darmstadt, Germany), KI (99.5\%, Merck, Darmstadt, Germany) and methanol (99.9\%, Merck, Darmstadt, Germany) which were bought from the Multi Kimia Raya store in Semarang, Indonesia. All chemical reagents used were analytical grade.

\subsection{HAP Catalyst Synthesis}

The method to synthesize the HAP catalyst followed Rivera et al. [17] with several modifications. In Rivera et al. [17], the eggshells were first heated at 2 stages, first at $450{ }^{\circ} \mathrm{C}$ for $2 \mathrm{~h}$ at a rate of $5^{\circ} \mathrm{C} / \mathrm{min}$ and second at $900{ }^{\circ} \mathrm{C}$ for $2 \mathrm{~h}$ at a rate of $0.5^{\circ} \mathrm{C} / \mathrm{min}$. After it was added to a solution, it was heated again to $1050{ }^{\circ} \mathrm{C}$ for $3 \mathrm{~h}$ at a rate of $10^{\circ} \mathrm{C} / \mathrm{min}$. While in this research, $50 \mathrm{~g}$ of phosphate rocks were 
ground and sieved to the distribution size of $100-400 \mu \mathrm{m}$. Then it was dissolved slowly in $500 \mathrm{~mL}$ of acid solution $\left(\mathrm{HNO}_{3} 1 \mathrm{M}, \mathrm{pH} 2\right)$ with high-speed stirring to maintain the $\mathrm{Ca}^{2+}$ and $\mathrm{H}_{3} \mathrm{PO}^{4-}$ ions. The solution was filtered and $\mathrm{NH}_{4} \mathrm{OH}$ was added to the filtrate until the $\mathrm{pH}$ reached 10 and left for $24 \mathrm{~h}$ until a white precipitate was formed. The precipitate was filtered and washed with distilled water until the $\mathrm{pH}$ of the filtrate was equal to the distilled water $\mathrm{pH}$, then dried at $110^{\circ} \mathrm{C}$. Calcination followed at $1050{ }^{\circ} \mathrm{C}$ for $4 \mathrm{~h}$ to produce the HAP catalyst. The next step was impregnation by dissolving KI and $\mathrm{KIO}_{3}$ solution in $50 \mathrm{~mL}$ of distilled water on concentration $1-6 \%(w / w)$. About $20 \mathrm{~g}$ of HAP was then mixed into the $\mathrm{KI}$ and $\mathrm{KIO}_{3}$ solution, stirred and heated for $2 \mathrm{~h}$ at $90{ }^{\circ} \mathrm{C}$. The solution was filtered with filter paper and the residue was dried.

\subsection{Catalyst Characterization}

The catalyst characterized was the non-impregnated catalyst and the catalyst impregnated with KI and $\mathrm{KIO}_{3}$. Catalyst characterization by XRD (X-ray diffraction, Bruker AXS D8 Diffractometer, Billerica, MA, USA) aimed to determine the crystallinity of the catalyst through the peaks at $2 \theta$. While SEM (scanning electron microscopy, (JSM-5410, JEOL, Tokyo, Japan) analysis was carried out to determine the surface morphology and pore distribution on the hydroxyapatite [12]. For other characterizations, FTIR (Perkin Elmer, Waltham, MA, USA) and BET (Quantachrome NOVA 1000 High- Speed Gas Sorption Analyser, Boynton Beach, FL, USA) were used to determine the functional group and pore size of the catalyst surface.

\subsection{Biodiesel Synthesis}

Biodiesel synthesis was carried out to test the performance of the catalyst. The method used was a one step simultaneous esterification and transesterification reaction in a batch reactor according to research conducted by Konwar et al. [2] with several modifications. Methanol and WCO with a mole ratio of 10:1 were prepared with the catalyst ( $1 \% w / w$ of WCO). The mixture was fed into a three-necked flask and heated until $60{ }^{\circ} \mathrm{C}$ with stirring at $800 \mathrm{rpm}$. The reaction will be terminated after $6 \mathrm{~h}$. To separate the product and the catalyst, the mixture was filtered with filter paper while glycerol was also separated in a separation funnel. Distillation was used to separate methanol from biodiesel products. The solid catalyst was then washed with n-hexane for reuse.

\subsection{Biodiesel Characterization}

The product was analyzed with GC-MS (gas chromatography mass spectrometry, Agilent 7890A, Wilmington, DE, USA) to determine the composition of FAME in the product. Biodiesel yield can be calculated using Equation (1):

$$
\text { Yield }=(\text { Biodiesel weight }) /(\text { WCO weight }) \times 100 \%
$$

Other biodiesel properties were also evaluated such as density, kinematic viscosity and FFA.

\section{Result and Discussion}

\subsection{Functional Group Analysis}

FTIR analysis (Figure 1) showed the functional groups in the HAP catalyst. The HAP functional group spectrum has a distribution of several points, which could be seen from the peak distributions alongside the wavenumber. Based on Figure 1, transmittance at $476-1035.75 \mathrm{~cm}^{-1}$ indicated there was a stretching and bending on the phosphate group $\left(\mathrm{PO}^{3-}\right)$, transmittance at $1421.2-1637.78 \mathrm{~cm}^{-1}$ showed that the functional group was carbonate $\left(\mathrm{CO}^{3-}\right)$ and the absorbance at $3448-3460.79 \mathrm{~cm}^{-1}$ identified a hydroxyl group $\left(\mathrm{OH}^{-}\right)$. These results show that the synthesized HAP had a high purity, which was in accordance with the research results of Yielmaz and Yilmaz [18] and Darwis et al. [19], although there was still a carbonate functional group present at a very small amount (trace element). 


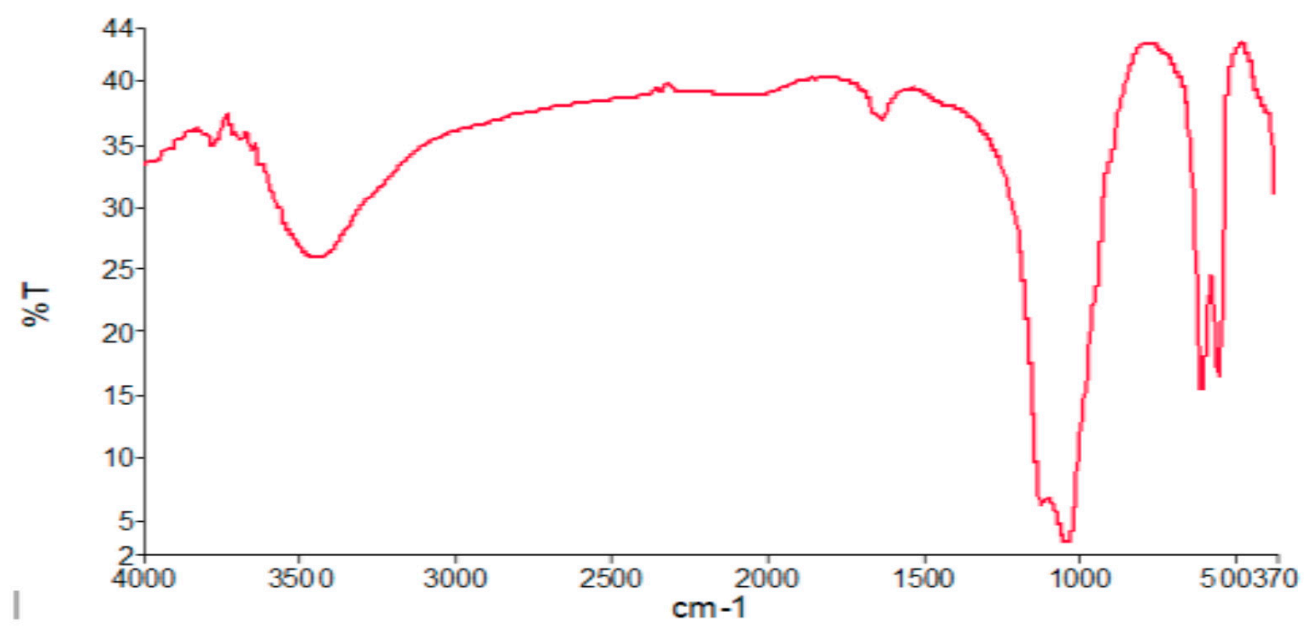

Figure 1. FTIR analysis result of HAP.

\subsection{XRD Analysis}

The XRD pattern was illustrated on the diffractogram profile (curve with peaks), with diffraction angle $2 \theta$ as the $x$-axis and diffraction intensity as the $y$-axis. Figure 2 shows the analysis of the diffractogram pattern of HAP and KI impregnated HAP catalysts. On the XRD pattern of the HAP catalyst without impregnation, the highest intensity peak identified belonged to hydroxyapatite, which was $31.854^{\circ}\left(\mathrm{Ca}_{5} \mathrm{P}_{3} \mathrm{HO}_{13}\right)$ and $32.970^{\circ}\left(\mathrm{Ca}_{5} \mathrm{P}_{3} \mathrm{HO}_{13}\right)$, with a hexagonal crystal system, matching with the COD 9,002,213 data. Said HAP catalyst had lattice parameters of $a=9.4081 \AA$ and $c=6.8887 \AA$ and also a density of $3.159 \mathrm{~g} / \mathrm{cm}^{3}$. The highest peak on $1 \% \mathrm{KI}$ impregnated was identified at $2 \theta=31.9^{\circ}$ $\left(\mathrm{Ca}_{5} \mathrm{P}_{3} \mathrm{HO}_{13}\right) ; 2 \% \mathrm{KI}$ impregnation at $2 \theta=31.9^{\circ}\left(\mathrm{Ca}_{5} \mathrm{P}_{3} \mathrm{HO}_{13}\right) ; 3 \% \mathrm{KI}$ impregnation at $2 \theta=31.157^{\circ}$ $\left(\mathrm{Ca}_{10.115} \mathrm{P}_{7} \mathrm{Mg}_{0.386} \mathrm{O}_{28}\right) ; 4 \% \mathrm{KI}$ impregnation at $2 \theta=31.16^{\circ}\left(\mathrm{Ca}_{10.115} \mathrm{P}_{7} \mathrm{Mg}_{0.385} \mathrm{O}_{28}\right) ; 5 \% \mathrm{KI}$ impregnation at $2 \theta=32.99^{\circ}\left(\mathrm{Ca}_{5} \mathrm{P}_{3} \mathrm{HO}_{13}\right)$; and $6 \% \mathrm{KI}$ impregnation at $2 \theta=31.91^{\circ}\left(\mathrm{Ca}_{5} \mathrm{P}_{3} \mathrm{HO}_{13}\right)$. In general, the highest peak of each KI impregnated sample was identified as hydroxyapatite, except for the $3 \%$ and $4 \%$ impregnation variables. However, the hydroxyapatite pattern was still present on the variables' peaks.

Figure 3 shows the XRD pattern of the HAP catalyst which was impregnated with $\mathrm{KIO}_{3}$. On $1 \%$ and $5 \%$ impregnation, the highest peak was identified at $2 \theta=31.890^{\circ}$ which belonged to HAP, and the diffractogram pattern matched the hydroxyapatite pattern (COD 9002213). $\mathrm{KIO}_{3}$ impregnation at $6 \%$ resulted in the pattern and highest peak at $2 \theta=31.830^{\circ}$ which matched the synthetic hydroxyapatite (ICDD No. 01-076-0694). This was different compared to the impregnation of $\mathrm{KIO}_{3}$ on $2 \%, 3 \%$ and $4 \%$ where the highest peaks identified were at $31.149^{\circ}\left(\mathrm{Ca}_{10.115} \mathrm{P}_{7} \mathrm{Mg}_{0.385} \mathrm{O}_{28}\right), 31.153^{\circ}\left(\mathrm{Ca}_{10.115} \mathrm{P}_{7} \mathrm{Mg}_{0.385}\right)$ and $31.175^{\circ}\left(\mathrm{Ca}_{10.115} \mathrm{P}_{7} \mathrm{Mg}_{0.385}\right)$ respectively. It could be due to the fact that during the calcination process, $\mathrm{Mg}$ was not eliminated and the hydroxyapatite crystal-forming reaction was not optimal. Hence, the functional group bonded to the apatite mineral was not the hydroxyl group, but $\mathrm{Mg}$. Generally, for all the catalyst samples, $\mathrm{KIO}_{3}$ was shown as the peaks at $2 \theta=34.530-34.550^{\circ}$ and $2 \theta=37.480-34.560^{\circ}$. The number of peaks and the intensity of $\mathrm{KIO}_{3}$ increased as the $\% w / w$ of impregnation increased [20]. 


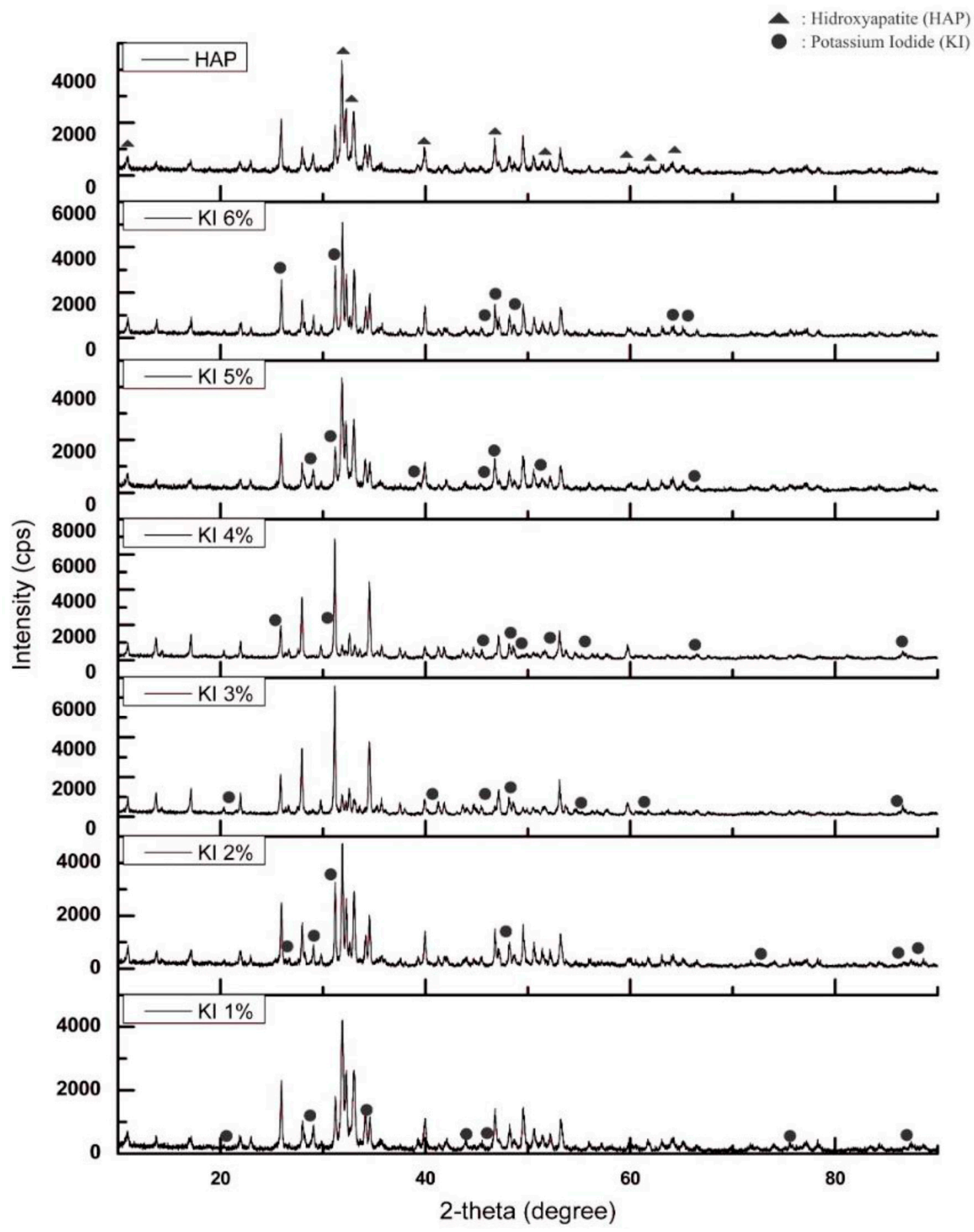

Figure 2. XRD pattern of HAP and KI/HAP catalyst. 


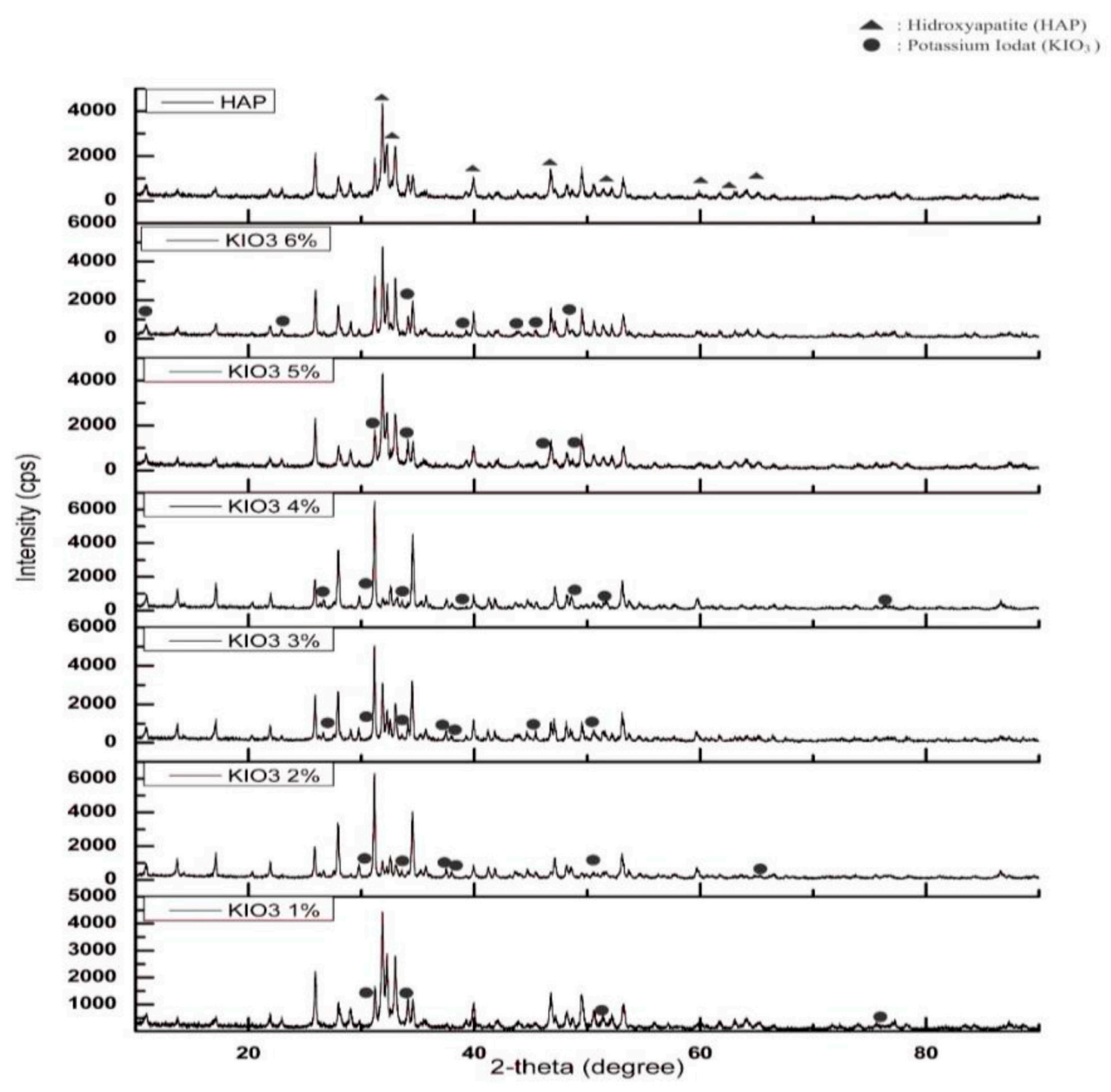

Figure 3. XRD pattern of $\mathrm{HAP}$ and $\mathrm{KIO}_{3} / \mathrm{HAP}$ catalyst.

\subsection{Catalyst Surface Area and Pore Volume Analysis}

Characterization of the surface area, catalyst pore volume and catalyst size were carried out with BET (Brunauer-Emmett-Teller) analysis. This analysis was based on the adsorption and desorption of nitrogen gas $\left(\mathrm{N}_{2}\right)$ on a porous solid (wide pore range) at a normal boiling point. The BET analysis results are shown in Table 1.

Table 1. BET analysis result.

\begin{tabular}{ccccc}
\hline \multirow{2}{*}{ Test Parameter } & \multirow{2}{*}{ Unit } & \multicolumn{3}{c}{ Catalyst } \\
\cline { 3 - 5 } & & HAP & KI/HAP (5\%) * & KIO $_{3} / \mathbf{H A P}_{\mathbf{~ ( 6 \% ) ~}}$ * \\
\hline Surface Area & $\mathrm{m}^{2} / \mathrm{g}$ & 21.631 & 13.513 & 10.651 \\
Pore Volume & $\mathrm{cc} / \mathrm{g}$ & 0.0330 & 0.0083 & 0.0065 \\
Pore Radius & $\AA$ & 16.330 & 7.380 & 6.830 \\
\hline
\end{tabular}

Note: ${ }^{*} \mathrm{KI} / \mathrm{HAP}(5 \%)$ and $\mathrm{KIO}_{3} / \mathrm{HAP}(6 \%)$ are the catalysts with the best performance.

According to IUPAC, the pore size of a porous solid could be categorized as micropore $(\mathrm{d}<20 \AA)$, mesopore $(20<\mathrm{dp}<500 \AA)$ and macropore $(\mathrm{dp}>500 \AA)$. Based on Table 1 , the HAP, KI/HAP $(5 \%)$ and $\mathrm{KIO}_{3} / \mathrm{HAP}(6 \%)$ catalysts from this research had a pore radius of $16.330 \AA, 7.38 \AA$ and $6.83 \AA$ 
respectively, and therefore fell into the micropore category. The surface area and pore volume from pure HAP (before impregnation) were $21.631 \mathrm{~m}^{2} / \mathrm{g}$ and $0.0330 \mathrm{cc} / \mathrm{g}$. After it was impregnated with $5 \% \mathrm{KI}$ and $6 \% \mathrm{KIO}_{3}$, there was a significant decrease in surface area and pore volume, to $10.651 \mathrm{~m}^{2} / \mathrm{g}$ and $0.0065 \mathrm{cc} / \mathrm{g}$. The decrease of surface area and pore volume can be tied to the changes on the surface of HAP which was covered by K compound. Furthermore, the effect of high-temperature sintering of HAP also led to catalyst particle agglomeration [11]. The obtained surface areas of the $\mathrm{HAP}, \mathrm{KI} / \mathrm{HAP}$ and $\mathrm{KIO}_{3} / \mathrm{HAP}$ catalysts were lower compared to the commercial HAP catalyst which typically had a surface area of $>100 \mathrm{~m}^{2} / \mathrm{g}$. This was attributed to the fact that wet impregnation was used as the method for catalyst synthesis, which resulted in the particles inevitably agglomerating hence yielding low a surface area, around $20-60 \mathrm{~m}^{2} / \mathrm{g}$ [21]. These findings were also reflected in a study of the $\mathrm{HAP} / \mathrm{K}_{2} \mathrm{CO}_{3}$ catalyst conducted by Chen et al. [12], where the surface area of the catalysts was $4.02-30.74 \mathrm{~m}^{2} / \mathrm{g}$ with a decreasing trend along with rising sintering temperature and $\mathrm{K}_{2} \mathrm{CO}_{3}$ loading as it was covered with $\mathrm{K}$ compound.

\subsection{Catalyst Surface Morphology Analysis}

The catalyst surface morphology structure was analyzed using SEM (scanning electron microscopy) with a $7500 \times$ magnification. The SEM observation results of the hydroxyapatite catalyst can be seen in Figure 4.

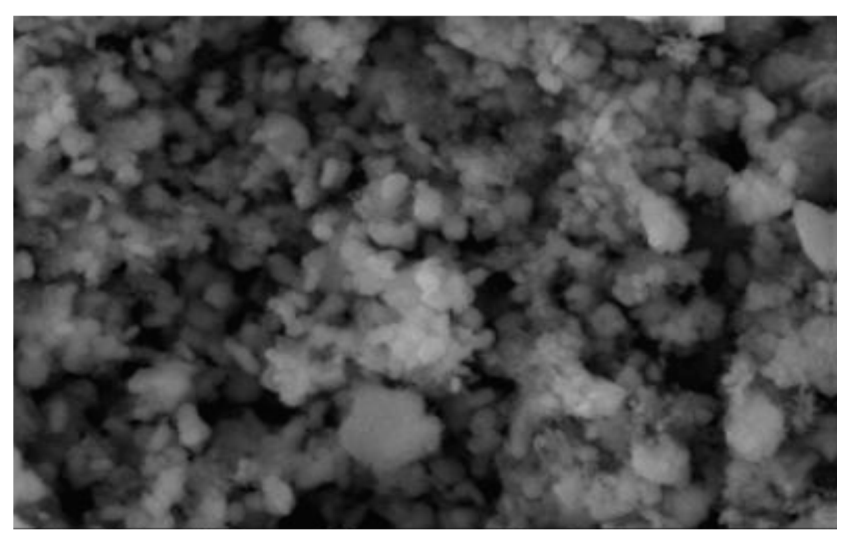

Figure 4. SEM result of the HAP catalyst.

The SEM analysis based on Figure 4 showed that the hydroxyapatite catalyst from this research had a crystalline structure and irregular glob form, similar to the one obtained by Kmieniak et al. [22], however with a better particle dispersion. The catalyst particle was not clearly shown to be hexagonal shaped, similar to the XRD results due to the agglomerate formation on some particles. High-temperature calcination will give the sintering effect on HAP which could lead to agglomeration of catalyst particles [11]. Gupta et al. [23] also explained that the sintering phenomena could result in particles to be more circular shaped and has a smoother surface.

The morphology of the catalyst surface which was impregnated with $\mathrm{KI}$ and $\mathrm{KIO}_{3}$ is shown in Figure 5 with a 10,000 $\times$ magnification. The presence of white dispersed glob indicates that KI and $\mathrm{KIO}_{3}$ had been impregnated. In Figure 5a, the KI particle formed an agglomerate that covered most of the catalyst's pore surface, while on Figure $5 \mathrm{~b}$ the $\mathrm{KIO}_{3}$ particle formed a thin layer which was distributed evenly on the catalyst surface. Compared with the hydroxyapatite SEM results in Figure 4a, HAP which has been impregnated did not give a significant morphological difference. This was due to the fact that the impregnation concentration variance used was only $1-6 \% w / w$. HAP which was impregnated with $\mathrm{KI}$ and $\mathrm{KIO}_{3}$ aimed to produce a basic property for the catalyst whilst maintaining a large surface area. The BET analysis results showed there was a decrease in HAP surface area after impregnation, but active surface for the catalysis reaction to happen was still present (sufficient). 

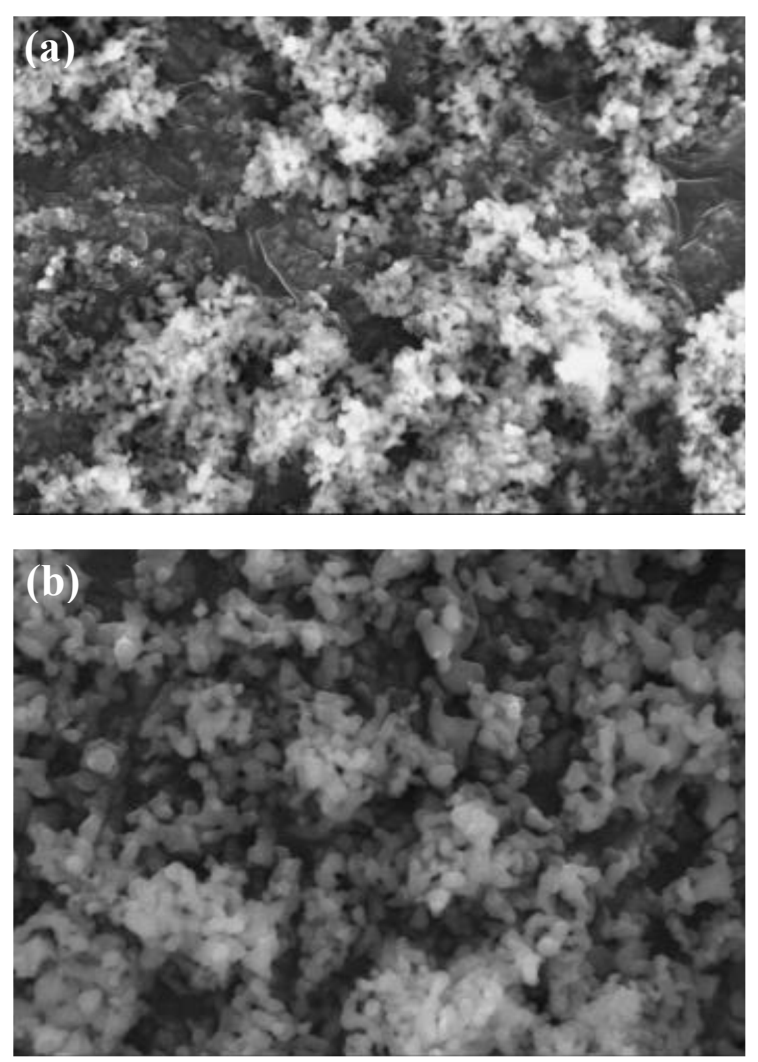

Figure 5. SEM result of impregnation.

\subsection{WCO Characterization}

The chemical composition of WCO was analyzed using GCMS, which is shown in Table 2. Other characteristics including density, viscosity and free fatty acid content were $0.944 \mathrm{~g} / \mathrm{cm}^{3}, 30.182 \mathrm{cSt}$ and $4.489 \%$ respectively. Waste cooking oil used in this research was mainly composed of hexadecenoic acid (93.65\%) which was palmitic acid. If compared to the research conducted by Abidin et al. [24], the fatty acid component of WCO was simpler. The difference between the composition of fatty acids contained in the WCO depended on the source of the oil, usage frequency and type of food fried in the oil as those factors will affect the chemical bonds and/or structure present in the oil [25].

Table 2. Fatty acid components in WCO.

\begin{tabular}{ccc}
\hline \multirow{2}{*}{ Component } & \multicolumn{2}{c}{ Composition $(\% \boldsymbol{w} / \boldsymbol{w})$} \\
\cline { 2 - 3 } & This Research & Abidin et al. [24] \\
\hline Octadecanoic acid (stearic acid) & 4.000 & 4.650 \\
9-Octadecenoic acid (oleic acid) & 2.100 & 33.750 \\
Hexadecenoic acid (palmitic acid) & 93.650 & 13.620 \\
Linoleic acid & & 43.850 \\
Linolenic acid & 100 & 4.650 \\
Total & 100 \\
\hline
\end{tabular}

\subsection{Heterogeneous Catalyst Reaction Mechanism}

$\mathrm{HAP}$ will act as an acid-base catalyst on a $\mathrm{Ca} / \mathrm{P}$ ratio of $1.500-1.670$. A low $\mathrm{Ca} / \mathrm{P}$ ratio will decrease the basic property from HAP [26]. The acid active site of HAP will act on the esterification reaction and the basic active site on the transesterification reaction. The transesterification reaction started with the formation of $\mathrm{OH}^{-}$or $\mathrm{RO}^{-}$as an active element. Methanol will be absorbed on the surface of the catalyst and then the ion-exchange process will happen. Next, an active catalytic RO- element is 
formed. The active element formed will attack the carbonyl function on the first triglyceride chain to form an intermediate. Next, there will be re-arrangement of the chain due to the break-down of the oxygen chain and the addition of proton $\mathrm{H}^{+}$to form FAME and diglyceride. The pathway would be repeated two times to form biodiesel and glycerol [27] (Figure 6).<smiles>[R]C(=O)OCC(COC([R])=O)OC([R2])(O)O[C@@H](C)COC([R])=O</smiles><smiles>[R]C(=O)OCC(O)COC([R])=O</smiles>

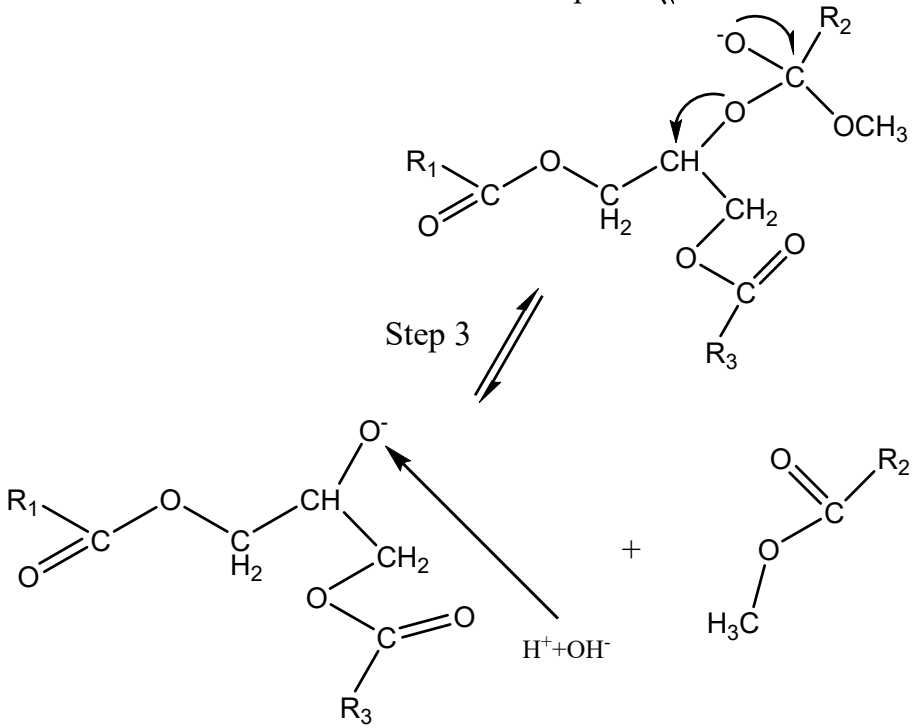

Figure 6. Biodiesel synthesis reaction mechanism.

Based on the chemical composition of the product on this research, the transesterification reaction which happened will not follow the general reaction pathway which was shown in Figure 6. This assumption was based on the GCMS analysis result which showed that a hexadecenoic acid, 2 hydroxy, 1,3 propanedixyl ester element was formed. The basic active site of $\mathrm{CH}_{3} \mathrm{O}^{-}$directly attacked the second palmitic chain of the triglyceride. This caused the hydroxyl functional group $\left(\mathrm{OH}^{-}\right) \mathrm{which}^{-}$ formed the glycerol structure to only replace one ester molecule, hence the reaction will stop at this step. As a consequence, the yield produced had a high viscosity as glycerol was not perfectly formed and separated from the biodiesel.

\subsection{Effect of Catalyst Type to Yield}

The performance of each catalyst was evaluated from the yield of biodiesel produced and FAME content which was analyzed using GCMS for an impregnation concentration of $1 \%$ to $6 \% w / w$. Figures 7 and 8 show the effect of catalyst type towards \% FAME and yield produced respectively. For the $\mathrm{KI} / \mathrm{HAP}$ catalyst, the yield and \% FAME showed an increasing trend up to $5 \%$ concentration; however, it decreased when the impregnation concentration was increased to $6 \%$. While on the $\mathrm{KIO}_{3} / \mathrm{HAP}$ catalyst, the yield and \% FAME tend to increase. The highest \% FAME obtained from the KI/HAP catalysts and $\mathrm{KIO}_{3} / \mathrm{HAP}$ catalysts were $59.100 \%$ and $57.130 \%$ respectively. Both graphs are represented through a polynomial equation by following the fluctuating pattern change of yield and \% FAME value on the catalyst impregnation concentration. The approach with polynomial regression was done to lessen the risks of determining an inaccurate target value caused by irregular data distribution. 
The fluctuation of yield and \% FAME value on the product was caused by the evaporation of liquid phase $\mathrm{KI} / \mathrm{KIO}_{3}$ when the impregnation process was carried out at a $90{ }^{\circ} \mathrm{C}$ temperature for $2 \mathrm{~h}$. The evaporation which took place was due to the fact that there was too little addition of $\mathrm{KI} / \mathrm{KIO}_{3}$. The evaporation phenomena which happened will affect the produced $\mathrm{KI} / \mathrm{KIO}_{3}$ composition.

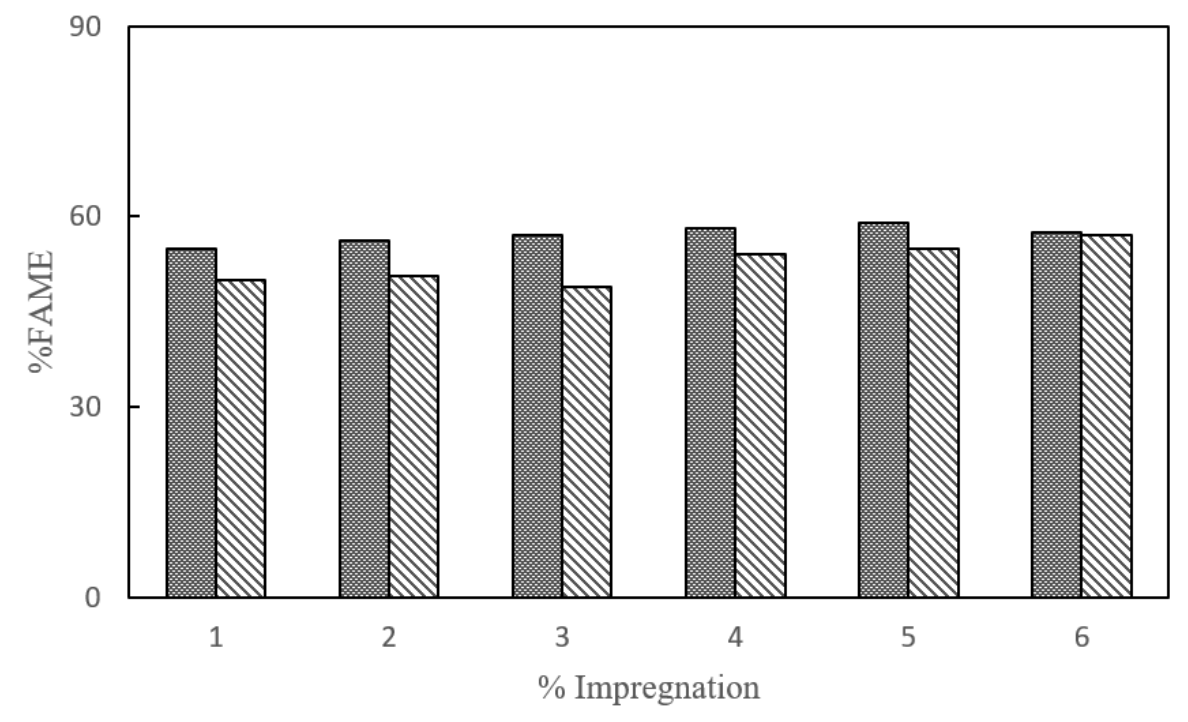

OFAME KI/HAP Q $\%$ \%FAME KIO3/HAP

Figure 7. Effect of catalyst type on \% FAME of biodiesel.

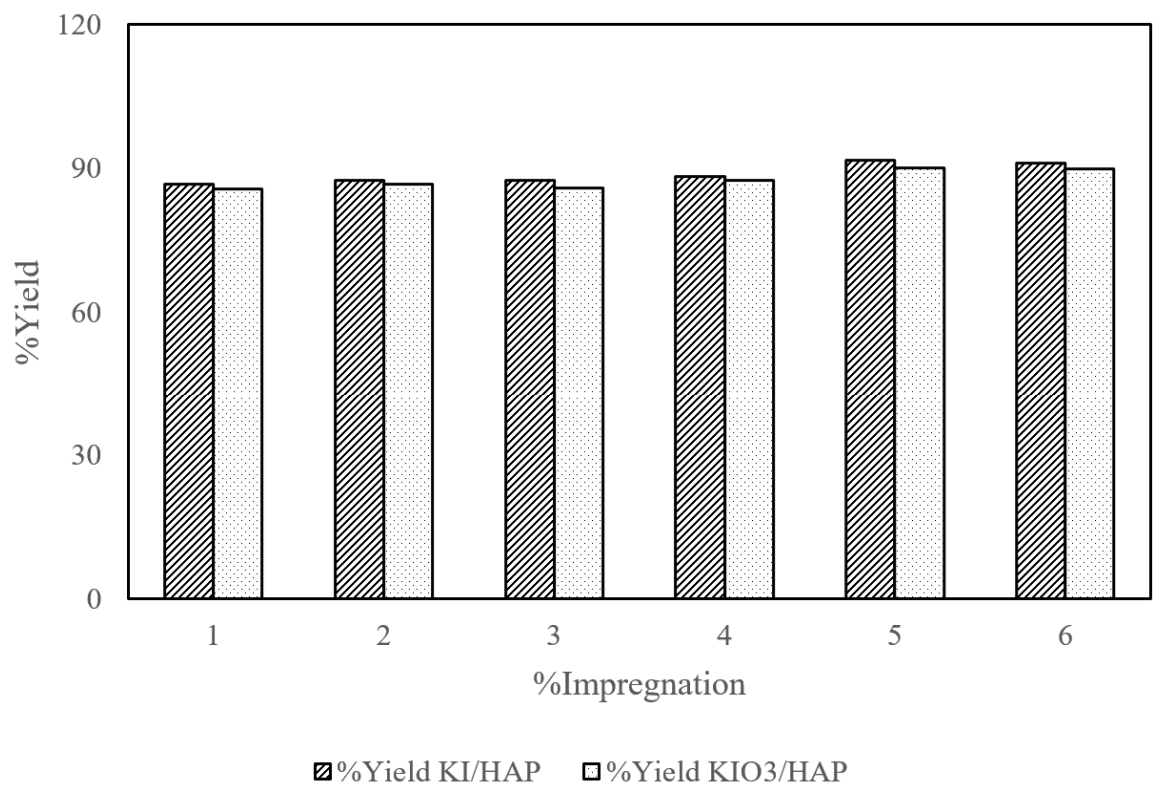

Figure 8. Effect of catalyst type to \% yield of biodiesel.

$\mathrm{KI} / \mathrm{HAP}$ resulted in the highest yield due to the fact that KI was basic in nature and had high catalytic activity. Research conducted by Razak et al. [28] showed the same results on the catalyst which was supported by alumina and KI. The decrease which happened on the catalyst with KI impregnation of $6 \%$ may have been caused by a reaction between $\mathrm{KI}$ and free fatty acid (FFA). A K ${ }^{+}$ion will react with the $\mathrm{OH}^{-}$to form a basic substance that will inhibit the catalytic reaction on transesterification. As a consequence, there will be a saponification reaction in the product, resulting in a decrease in the product yield. Although both yield and FAME results have similar trends between the KI impregnated and $\mathrm{KIO}_{3}$ impregnated catalyst, these were also mirrored in a study by Widayat et al. [29] who synthesized 
$\mathrm{KI} / \mathrm{KIO}_{3}$ impregnated zeolite $\mathrm{H}(1-5 \% w / w)$ and got similar biodiesel conversion trends between $\mathrm{KI}$ and $\mathrm{KIO}_{3}$ impregnated zeolite (80-87.91\%). Other studies including biodiesel production with $\mathrm{Al} / \mathrm{KI}$ and $\mathrm{Al} / \mathrm{CaO} / \mathrm{KI}$ catalysts have also shown similar trends between 80-90\% yield with 1-3.5\% KI loading [28] and biodiesel production with a $\mathrm{KI} / \gamma-\mathrm{Al}_{2} \mathrm{O}_{3}$ catalyst which yields similar trends on \% FAME yield with $0.15-0.33 \% w / w$ KI loading [13]. These similar trends were due to the fact that KI can readily dissolve in methanol, hence giving a highly basic nature leading to high adsorptive sites for alcohol transesterification that gave similar yield and \% FAME trends.

\subsection{Biodiesel Product Characterization}

The biodiesel produced in this research was characterized by three test parameters: density, viscosity and FFA content. These parameters served as a comparison standard to the Indonesian National Standard (SNI 7182-2015) and European Standard (EN 14214:2008) of biodiesel. Based on Tables 3 and 4 it can be seen that with increasing the catalyst impregnation percentage $\left(\mathrm{KI}_{\text {or }} \mathrm{KIO}_{3}\right)$, the density and viscosity of the products decreased. The decrease of density was caused by triglyceride on the waste cooking oil being broken down to form methyl ester and glycerol. The products formed had a density range of $0.9032-0.9005 \mathrm{~g} / \mathrm{cm}^{3}$ and viscosity of $28.080-20.790 \mathrm{cSt}$ at room temperature. Waste cooking oil used as a raw material has an FFA content of $4.900 \%$, while the FFA content of the product was in the range of $1.726-1.876 \%$ for $\mathrm{KI}$ impregnated and $1.759-1.815 \%$ for $\mathrm{KIO}_{3}$ impregnated. The FFA content of the product decreased on each increasing impregnation value for $\mathrm{KI}$ and $\mathrm{KIO}_{3}$.

Table 3. Biodiesel characteristic using the HAP/KI catalyst.

\begin{tabular}{|c|c|c|c|c|c|c|c|c|}
\hline \multirow{2}{*}{ Test Parameter } & \multicolumn{6}{|c|}{ KI impregnation $(\% w / w)$} & \multirow{2}{*}{$\begin{array}{l}\text { Indonesian } \\
\text { Standard }\end{array}$} & \multirow{2}{*}{$\begin{array}{l}\text { European } \\
\text { Standard }\end{array}$} \\
\hline & $1 \%$ & $2 \%$ & $3 \%$ & $4 \%$ & $5 \%$ & $6 \%$ & & \\
\hline Density $\left(\mathrm{g} / \mathrm{cm}^{3}\right)$ & 0.873 & 0.868 & 0.864 & 0.861 & 0.859 & 0.861 & $0.850-0.900$ & $0.860-0.900$ \\
\hline Viscosity (cSt) & 7.803 & 6.465 & 6.242 & 6.688 & 5.574 & 5.797 & Max. 6 at $40^{\circ} \mathrm{C}$ & $3.5-5.0$ at $40^{\circ} \mathrm{C}$ \\
\hline$\%$ FFA & 1.876 & 1.721 & 1.753 & 1.817 & 1.787 & 1.726 & $<1$ & $<1$ \\
\hline
\end{tabular}

Table 4. Biodiesel characteristic using the $\mathrm{HAP} / \mathrm{KIO}_{3}$ catalyst.

\begin{tabular}{|c|c|c|c|c|c|c|c|c|}
\hline \multirow{2}{*}{ Test Parameter } & \multicolumn{6}{|c|}{ KI Impregnation $(\% w / w)$} & \multirow{2}{*}{$\begin{array}{l}\text { Indonesian } \\
\text { Standard }\end{array}$} & \multirow{2}{*}{$\begin{array}{l}\text { European } \\
\text { Standard }\end{array}$} \\
\hline & $1 \%$ & $2 \%$ & $3 \%$ & $4 \%$ & $5 \%$ & $6 \%$ & & \\
\hline Density $\left(\mathrm{g} / \mathrm{cm}^{3}\right)$ & 0.875 & 0.871 & 0.868 & 0.861 & 0.863 & 0.854 & $0.850-0.900$ & $0.860-0.900$ \\
\hline Viscosity (cSt) & 8.249 & 6.242 & 6.020 & 6.911 & 6.020 & 5.797 & Max. 6 at $40^{\circ} \mathrm{C}$ & $3.5-5.0$ at $40{ }^{\circ} \mathrm{C}$ \\
\hline$\%$ FFA & 1.815 & 1.879 & 1.848 & 1.819 & 1.789 & 1.759 & $<1$ & $<1$ \\
\hline
\end{tabular}

According to the Indonesian standard, biodiesel has a density range of $0.850-0.900 \mathrm{~g} / \mathrm{cm}^{3}$ and viscosity of $2.860 \mathrm{cSt}$ at $40^{\circ} \mathrm{C}$, while the European standard stated biodiesel the density and viscosity values to be in the range of $0.860-0.900 \mathrm{~g} / \mathrm{cm}^{3}$ and $3.5-5.0 \mathrm{cSt}$ at $40{ }^{\circ} \mathrm{C}$ respectively. Hence the quality of products for variables $1-4 \% \mathrm{KI}$ and $1-5 \% \mathrm{KIO}_{3}$ produced did not meet either the Indonesian or European required standard. This phenomenon was caused by the first chain (R1) and the third chain (R3) on the triglyceride yet to be broken down, hence less glycerol and methyl ester produced. In Figure 6 it could be seen that methanol only attacked the second triglyceride chain (R2), therefore forming a substance with a high molecular weight, such as 1,3-propanedyl ester. The density value was directly proportional to the product mass, thus increasing the product mass will yield higher density over the same volume. The high viscosity of the product was due to the imperfectly broken-down triglyceride chain which led to the formation of glycerol along with FAME. As the viscosity of glycerol was higher than that of FAME, the presence of glycerol would increase viscosity. 


\subsection{Biodiesel Product Chemical Composition}

Based on the chromatogram from the GCMS analysis, the biodiesel synthesized consisted of the components in Table 5. The methyl ester was formed from hexadecanoic acid, 9-octadecenoic acid and octadecanoic acid. Those results were proportional to the fatty acid composition of WCO used as a raw material. Other than the methyl ester components, propanediyl ester which contained an $\mathrm{OH}$ functional group was also formed. The formation of this component was due to the molar ratio of methanol and oil used was still less than required, leading to the imperfect glycerol formation and hence separated from the product following the reaction mechanism in Figure 6. This was also proportional to the biodiesel characteristics where it has not met the required Indonesian nor European standard yet.

Table 5. Biodiesel components.

\begin{tabular}{|c|c|c|}
\hline Compounds & Molecular Formulas & Chemical Structure \\
\hline Hexadecanoic acid, methyl ester (CAS) & $\mathrm{C}_{17} \mathrm{H}_{34} \mathrm{O}_{2}$ & \\
\hline 9-Octadecenoic acid, methyl ester (CAS) & $\mathrm{C}_{19} \mathrm{H}_{36} \mathrm{O}_{2}$ & \\
\hline $\begin{array}{c}\text { Hexadecanoic acid, } \\
\text { 2-hydroxy-1,3-propannediyl ester (CAS) }\end{array}$ & $\mathrm{C}_{35} \mathrm{H}_{68} \mathrm{O}_{5}$ & \\
\hline $\begin{array}{c}\text { Octadecanoic acid, } \\
\text { 2-hydroxy-1,3-propanediyl ester }\end{array}$ & $\mathrm{C}_{39} \mathrm{H}_{76} \mathrm{O}_{5}$ & \\
\hline Di-(9-octadecenoyl)-glycerol & $\mathrm{C}_{57} \mathrm{H}_{102} \mathrm{O}_{6}$ & \\
\hline
\end{tabular}

\subsection{Catalyst Reusability}

The catalyst reusability test was carried out using the highest biodiesel yielding catalyst (KI/HAP 5\%) with a simultaneous esterification and transesterification reaction method and three repetitions. Before the reusability test, methanol and oil which stuck to the catalyst were washed with n-hexane, then dried at $110{ }^{\circ} \mathrm{C}$. The yields obtained were $85.6 \%, 83.8 \%$ and $72.1 \%$. The decrease in yield obtained was caused by the pore of catalyst being covered with oil in the reaction. Cakraborty and Roychowdhury [30] explained that the decrease in catalytic activity was caused by the leaching of active species in the catalyst to the reaction media when it was used repeatedly. This statement was also supported by Chen et al. [12] where they conducted a leaching study on HAP supported a $\mathrm{K}_{2} \mathrm{CO}_{3}$ catalyst for biodiesel production. The results from the EDS analysis performed between fresh and an eight-cycle-old $\mathrm{HAP} / \mathrm{K}_{2} \mathrm{CO}_{3}$ catalyst showed that the doped $\mathrm{K}$ content was lower in the eight-cycle-old catalyst, indicating that repeated usage will cause the $\mathrm{K}$ compound to leach out, leading to loss of catalytic activity of the catalyst.

Figure 9 shows the morphology of the catalyst surface after three cycles of use. The surface of the catalyst is more covered with globular particles when compared to the KI/HAP catalyst in Figure 5a. Those particles which covered the pore could be oil, biodiesel or glycerol. According to Istadi et al. [31], factors that could decrease the catalytic activity of catalyst include species leaching from the catalyst's active site to the methanol phase [12,31,32], poisoning of the catalyst by the reaction media and also a broken catalyst structure.

Industries generally use homogeneous catalysts such as $\mathrm{H}_{2} \mathrm{SO}_{4}, \mathrm{HCl}, \mathrm{NaOH}$ or $\mathrm{KOH}$ to commercially produce biodiesel via a transesterification reaction [33]. Su [34] conducted a recoverability and reusability study on $\mathrm{H}_{2} \mathrm{SO}_{4}, \mathrm{HCl}$ and $\mathrm{HNO}_{3}$ catalysts for biodiesel production from soybean oil. The study concluded $\mathrm{HCl}$ has the highest recoverability $\left(99.75 \%\right.$ ), while $\mathrm{HNO}_{3}$ and $\mathrm{H}_{2} \mathrm{SO}_{4}$ recoverability were 69.25 and $57.75 \%$ respectively. The reusability of the $\mathrm{HCl}$ catalyst was further 
examined and the results stated after five times of reuse there was no significant difference of FFA conversion (98.19\%). Karmee et al. [35] performed a techno-economic evaluation study on biodiesel production using WCO as raw material and $\mathrm{H}_{2} \mathrm{SO}_{4}, \mathrm{KOH}$ and Novozym-435 as catalysts. It was found that the Novozym-435 catalyst could be recycled 200 times in 30 days without a significant decrease in the biodiesel yield (80\%). A HAP supported $\mathrm{CaO}-\mathrm{CeO}_{2}$ catalyst for biodiesel production with palm oil as a raw material was also investigated for its reusability by Yan et al. [32] where it was found that a catalyst with synthetic HAP had better performance and no significant decrease in yield (83\%) after eight times of reuse compared to natural HAP from calcined bones. A similar study on a HAP supported $\mathrm{K}_{2} \mathrm{CO}_{3}$ catalyst conducted by Chen et al. [12] showed above $90 \%$ biodiesel yield for $30 \%$ $w / w \mathrm{~K}$ doped at $600{ }^{\circ} \mathrm{C}$ calcination, $85 \%$ for $40 \% w / w \mathrm{~K}$ doped at $600{ }^{\circ} \mathrm{C}$ and $79 \%$ for $30 \% w / w \mathrm{~K}$ doped at $500{ }^{\circ} \mathrm{C}$ after eight times of reuse. Therefore, it could be concluded that the number of times on which a catalyst can be reused depended on the conversion/yield, as a lower conversion often resulted in higher operating costs and inefficiency of the system. The KI/HAP 5\% catalyst synthesized in this study hence could be concluded still favorable after three times of reuse based on the yield obtained $(72.100 \%)$ compared to the mentioned studies.

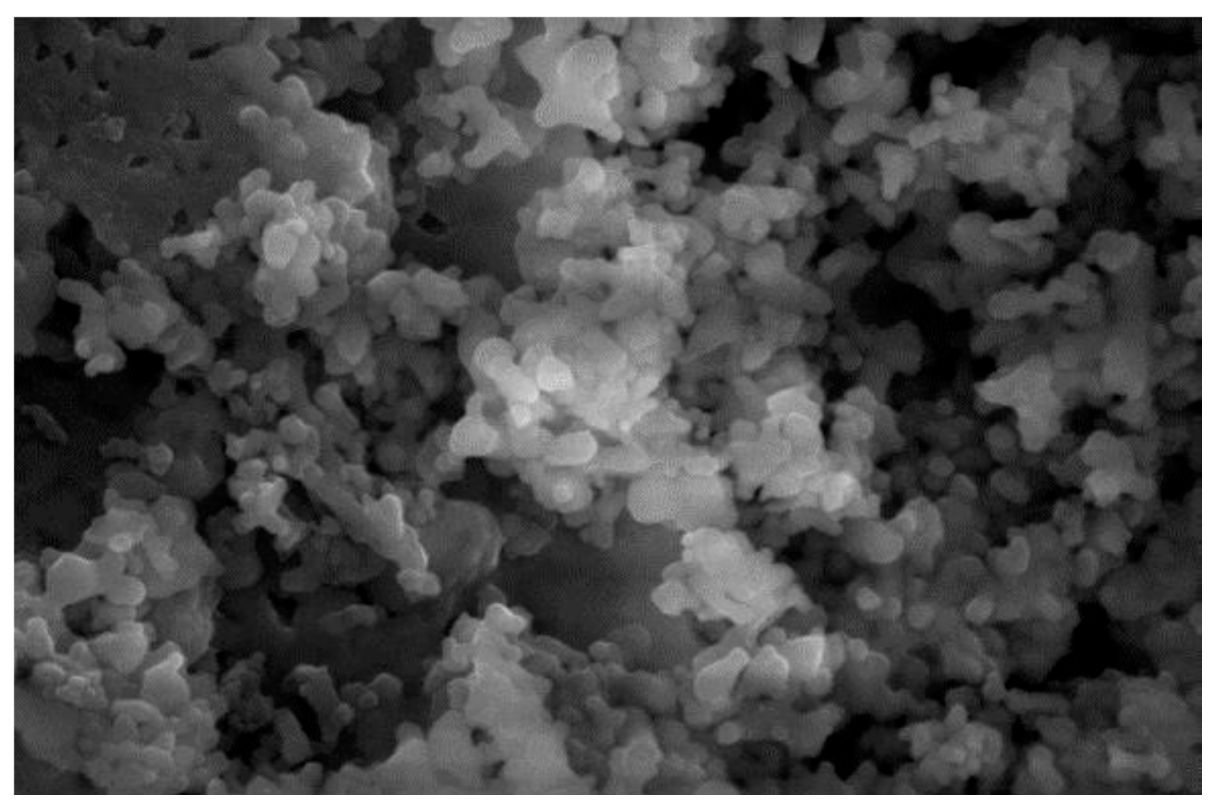

Figure 9. SEM result of the KI/HAP catalyst after three cycles of use.

\section{Conclusions}

This study explored the possibility of $\mathrm{KI} / \mathrm{HAP}$ and $\mathrm{KIO}_{3} / \mathrm{HAP}$ catalysts for biodiesel production. The catalyst characterization showed that pure HAP catalyst was successfully synthesized by calcination at $1050{ }^{\circ} \mathrm{C}$ for $4 \mathrm{~h}$. After $\mathrm{KI} / \mathrm{HAP}$ and $\mathrm{KIO}_{3} / \mathrm{HAP}$ impregnations, it showed a crystalline structure shaped in an irregular agglomerate with a surface area of $13.513 \mathrm{~m}^{2} / \mathrm{g}$ and $10.651 \mathrm{~m}^{2} / \mathrm{g}$, and pore volume $0.0083 \mathrm{cc} / \mathrm{g}$ and $0.0065 \mathrm{cc} / \mathrm{g}$ respectively. The catalytic activity of $\mathrm{KI} / \mathrm{HAP}$ and $\mathrm{KIO}_{3} / \mathrm{HAP}_{\text {was }}$ evaluated based on yield and \% FAME produced. The highest yield was obtained on KI/HAP catalyst for $91.780 \%$ and FAME, $59.100 \%$. The results show that the KI/HAP catalyst had better performance and characteristics as compared to the $\mathrm{KIO}_{3} / \mathrm{HAP}$ catalyst as it has a larger surface area, $13.513 \mathrm{~m}^{2} / \mathrm{g}$ and higher yield, 91.780\%. The impregnation concentration of $\mathrm{KI}$ and $\mathrm{KIO}_{3}$ affected the catalyst performance which can be evaluated by the characteristics of the biodiesel produced. Increasing the impregnation concentration of $\mathrm{KI}$ and $\mathrm{KIO}_{3}$ resulted in a positive response to the yield and \% FAME. The sustainability of the catalyst was investigated by its reusability where the results indicated that after three times of use, the catalyst was still favorable and produced $72.100 \%$ biodiesel yield. Further research for this work includes a leaching test to confirm the decreased catalytic activity on 
repeated usage and a biodiesel performance test on deriving energy to further attest the capability of the KI/HAP catalyst in biodiesel production. The optimization of the catalyst under the response surface methodology is also worth studying in future research in this area.

Author Contributions: Conceptualization, W.W.; methodology, W.W.; validation, P.W.A.W., J.P. and U.A.Z.; formal analysis, J.P.; investigation, P.W.A.W. and U.A.Z.; resources, W.W.; data curation, H.H.; writing-original draft preparation, W.W. and H.H.; writing-review and editing, H.H.; funding acquisition, W.W. All authors have read and agreed to the published version of the manuscript.

Funding: This research is supported and funded by the Ministry of Research, Technology and Higher Education of Republic of Indonesia Penelitian Dasar Unggulan Perguruan Tinggi (No. SPK 257-70/UN7.P4.3/PP/2019) Grant.

Conflicts of Interest: The authors declare no conflict of interest.

\section{References}

1. Knothe, G.; Razon, L.F. Biodiesel Fuels. Prog. Energy Combust. Sci. 2017, 58, 36-59. [CrossRef]

2. Konwar, L.J.; Warna, J.; Arvela, P.M.; Kumar, N.; Mikkola, J.P. Reaction Kinetics with Catalyst Deactivation in Simultaneous Esterification and Transesterification of Acid Oils to Biodiesel (FAME) Over A Mesoporous Sulphonated Carbon Catalyst. Fuel J. 2016, 166, 1-11. [CrossRef]

3. Mohandass, R.; Ashok, K.; Selvaraju, A. Homogeneous Catalysts Used in Biodiesel Production: A Review. Int. J. Eng. Res. Technol. 2016, 5, 264-268. [CrossRef]

4. Ferreira, R.S.B.; dos Passos, R.M.; Sampaio, K.A.; Batista, E.A. Heterogeneous Catalysts for Biodiesel Production: A Review. Food Public Health 2019, 9, 125-137.

5. Encinar, J.M.; Gonzalez, J.F.; Sanchez, N.; Nogales-Delgado, S. Sunflower Oil Transesterification with Methanol Using Immobilized Lipase Enzymes. Bioprocess Biosyst. Eng. 2018, 42, 157-166. [CrossRef] [PubMed]

6. Sulaiman, S.; Khairudin, N.; Jamal, P.; Alam, M.Z.; Zainudin, Z.; Azmi, S. Characterization of Fish Bone Catalyst for Biodiesel Production. Int. J. Chem. Mol. Eng. 2014, 8, 464-466.

7. Xie, W.; Huang, M. Enzymatic Production of Biodiesel Using Immobilized Lipase on Core-Shell Structure $\mathrm{Fe}_{3} \mathrm{O}_{4} @ \mathrm{MIL}-100(\mathrm{Fe})$ Composites. Catalysts 2019, 9, 850. [CrossRef]

8. Romero, R.; Martinez, S.L.; Natividad, R. Biodiesel Production by Using Heterogeneous Catalysts. In Alternative Fuel; Manzanera, M., Ed.; IntechOpen: Rijeka, Croatia, 2011. [CrossRef]

9. Kasno, A.; Rochayati, S.; Prasetyo, B.H. Deposit, Penyebaran dan Karakteristik Fosfat Alam; Balai Penelitian Tanah Kementrian Pertanian: Kota Bogor, Indonesia, 2009.

10. Khan, H.M.; Iqbal, T.; Ali, C.H.; Yasin, S.; Jamil, F. Waste quail beaks as renewable source for synthesizing novel catalysts for biodiesel production. Renew. Energy 2020, 154, 1035-1043. [CrossRef]

11. Essamlali, Y.; Amadine, O.; Larzek, M.; Len, C.; Zahouily, M. Sodium Modified Hydroxyapatite: Highly Efficient and Stable Solid-Base Catalyst for Biodiesel Production. Energy Convers. Manag. 2017, 149, 355-367. [CrossRef]

12. Chen, G.; Shan, R.; Shi, J.; Liu, C.; Yan, B. Biodiesel Production from Palm Oil Using Active and Stable K Doped Hydroxyapatite Catalyst. Energy Convers. Manag. J. 2015, 98, 463-469. [CrossRef]

13. Islam, A.; Taufiq-Yap, Y.H.; Ravindra, P.; Teo, S.H.; Sivasangar, S.; Chan, E.S. Biodiesel Synthesis over Millimetric $\gamma-\mathrm{Al}_{2} \mathrm{O}_{3} / \mathrm{KI}$ catalyst. Energy 2015, 89, 965-973. [CrossRef]

14. Malani, R.S.; Shinde, V.; Ayachit, S.; Goyal, A.; Moholkar, V.S. Ultrasound-assisted Biodiesel Production Using Heterogeneous Base Catalyst and Mixed Non-edible Oils. Ultrason. Sonochem. 2019, 52, 232-243. [CrossRef] [PubMed]

15. Tantirungrotechai, J.; Chotmongkolsap, P.; Pohmakotr, M. Synthesis, Characterization and Activity in Transesterification of Mesoporous Mg-Al Mixed-Metal Oxides. Microporous Mesoporous Mater. 2010, 128, 41-47. [CrossRef]

16. Jairam, S.; Kolar, P.; Sharma-Shivappa, R.; Osborne, J.A.; Davis, J.P. KI-impregnated Oyster Shell as a Solid Catalyst for Soybean Oil Transesterification. Bioresour. Technol. 2012, 104, 329-335. [CrossRef]

17. Rivera, E.M.; Araiza, M.; Brostow, W.; Castano, V.M.; Diaz-Estrada, J.R.; Hernandez, R.; Rodriguez, J.R. Synthesis of Hydroxyapatite from Eggshells. Mater. Lett. 1999, 41, 128-134. [CrossRef]

18. Yielmaz, A.; Yilmaz, S. Wet Chemical Precipitation Synthesis of Hydroxyapatite (HA) Powders. Ceram. Int. 2018, 44, 9703-9710. [CrossRef] 
19. Darwis, D.; Warastuti, Y.; Sugiyono, K. Sintesis dan Karakterisasi Komposit Hidroksiapatite (HA) Sebagai Graft Tulang Sintetik. J. Ilm. Apl. Isot. Dan Radiasi 2008, 4, 143-153.

20. Kytin, V.V.K.; Dyulgerova, E.; Ilievac, R.; Petkova, V. Powder X-ray Diffraction Studies of Hydroxyapatite and $\beta$-TCP Mixtures Processed by High Energy Dry Milling. Ceram. Int. 2018, 44, 8664-8671. [CrossRef]

21. Uota, M.; Arakawa, H.; Kitamura, N.; Yoshimura, T.; Tanaka, J.; Kijima, T. Synthesis of High Surface Area Hydroxyapatite Nanoparticles by Mixed Surfactant-Mediated Approach. Langmuir 2005, 21, 4724-4728. [CrossRef]

22. Kamieniak, J.; Bernalte, E.; Foster, C.W.; Doyle, A.M.; Kelly, P.J.; Banks, C.E. High Yield Synthesis of Hydroxyapatite (HAP) and Palladium Doped HAP via Wet Chemical Synthetic Route. J. Catal. 2016, 6, 119. [CrossRef]

23. Gupta, J.; Agarwal, M.; Dalai, A.K. Marble Slurry Derived Hydroxyapatite as Heterogeneous Catalyst for Biodiesel Production from Soy Bean Oil. Can. J. Chem. Eng. 2018, 96, 1871-1876. [CrossRef]

24. Abidin, S.Z.; Patel, D.; Saha, B. Quantitative Analysis of Fatty Acids Composition in the Used Cooking Oil (UCO) by Gas Chromatography Mass Spectrometry. Can. J. Chem. Eng. 2013, 91, 1896-1903. [CrossRef]

25. Banani, R.; Youssef, S.; Bezzarga, M.; Abderrabba, M. Waste frying oil with 412 high levels of free fatty acids as one of the prominent sources of biodiesel production. J. Mater. Environ. Sci. 2015, 6, 1178-1185.

26. Garcia, S.D.; Osman, M.B.; Krafft, J.M.; Cassale, S.; Thomas, C.; Kubo, J.; Costentin, G. Identification of Surface Basic Sites and Acid-Base Pairs of Hydroxyapatite. J. Phys. Chem. 2016, 118, 12744-12757.

27. Guo, F.; Wei, N.N.; Xiu, Z.L.; Fang, Z. Transesterification mechanism of soybean oil to biodiesel catalyzed by calcined sodium silicate. Fuel 2012, 93. [CrossRef]

28. Razak, Z.K.A.; Kamarullah, S.H.; Khazaai, S.N.M.; Maniam, G.P. Synthesis of Alumina-CaO-KI Catalyst for the Production of Biodiesel from Rubber Seed Oil. Malays. J. Anal. Sci. 2018, 22, 279-285.

29. Widayat, W.; Wicaksono, A.R.; Firdaus, L.H.; Okvitarini, N. Synthesis H-Zeolite Catalyst by Impregnation $\mathrm{KI} / \mathrm{KIO}_{3}$ and Performance Test Catalyst for Biodiesel Production. Mater. Sci. Eng. 2016, 107. [CrossRef]

30. Cakraborty, R.; Roychowdhury, D. Fish Bone Derived Natural Hydroxyapatite-Supported Copper Acid Catalyst: Taguchi Optimization of Semi-batch Oleic Acid Esterification. Chem. Eng. J. 2012, 215-216, 491-499.

31. Istadi, I.; Mabruro, U.; Kalimantini, B.A.; Buchori, L.; Anggoro, D.D. Reusability and Stability Tests of Calcium Oxide Based Catalyst (K2O/CaO-ZnO) for Transesterification of Soybean Oil to Biodiesel. Bull. Chem. React. Eng. Catal. 2016, 11, 34-39.

32. Yan, B.; Zhang, Y.; Chen, G.; Shan, R.; Ma, W.; Liu, C. The Utilization of Hydroxyapatite-Supported CaO-CeO 2 Catalyst for Biodiesel Production. Energy Convers. Manag. 2016, 130, 156-164. [CrossRef]

33. Thangaraj, B.; Solomon, P.R.; Muniyandi, B. Catalysis in Biodiesel Production-A Review. Clean Energy 2019, 3, 2-23. [CrossRef]

34. Su, C.H. Recoverable and Reusable Hydrochloric Acid Used as a Homogeneous Catalyst for Biodiesel Production. Appl. Energy 2013, 104, 503-509. [CrossRef]

35. Karmee, S.K.; Patria, R.D.; Lin, C.Z.K. Techno-Economic Evaluation of Biodiesel Production from Waste Cooking Oil-A Case Study of Hong Kong. Int. J. Mol. Sci. 2015, 16, 4362-4371. [CrossRef] [PubMed]

(C) 2020 by the authors. Licensee MDPI, Basel, Switzerland. This article is an open access article distributed under the terms and conditions of the Creative Commons Attribution (CC BY) license (http://creativecommons.org/licenses/by/4.0/). 